Date of Publication: $18 / 11 / 2013$

\section{Cunninghamia}

A journal of plant ecology for eastern Australia
\& Domain Trust

ISSN $0727-9620$ (print) • ISSN 2200 -405X (Online)

\title{
Upland wetlands in the Namoi Catchment: mapping distribution and disturbance classes of fens, bogs and lagoons
}

\author{
John T. Hunter \\ School of Behavioural, Cognitive and Social Sciences, University of New England, Armidale, NSW 2351 AUSTRALIA
}

\begin{abstract}
To assist with planning and conservation strategies, mapping of wetlands above 700 m elevation across the Namoi Catchment (east of Tamworth) was undertaken. The number of hectares of each type within this high-elevation region, the area currently in conservation reserves and the status of these remnants was assessed. 1001 wetlands were mapped and allocated to three wetland types (fens, bogs and lagoons) and six disturbance groups (based on agricultural clearing and presence of dams). Total wetlands cover was 4490 ha, of which fens were the most common, followed by bogs and a single lagoon. The smallest wetland was 0.12 ha in size, the largest 113 ha and the average 5 ha. Only $10 \%$ of all wetlands were considered to be in near natural state with only $5.5 \%$ of all wetland area protected within conservation reserves.
\end{abstract}

Cunninghamia (2013) 13: 331-335

doi: 10.7751cunninghamia2013.009

\section{Introduction}

Only a very small amount of the Australian land area is montane environment; much of this occurs along a belt of uplift on the eastern seaboard known as the Great Dividing Range (extending from Cape York Peninsula south to Tasmania). The New England Tableland Bioregion forms a major part of this upland area, incorporating an area of about three million hectares $(3,004,202$ ha), about $3.6 \%$ of the state of New South Wales. Three broad categories of freshwater wetlands locally known as lagoons, fens and bogs occur in this region (Hunter \& Bell 2007; Bell et al. 2008; Hunter \& Bell 2009). In conservation terms all of these wetland types are considered threatened.

The lagoons are shallow temporary lentic wetlands occurring at altitudes above $900 \mathrm{~m}$ dominated by emergent macrophytes (Bell et al. 2008). They are mostly oval-shaped, often with a distinct rocky margin, with considerable recent silt accumulation on their edges, in some cases forming sand dunes or clay-rich mounts on their eastern side called 'lunettes' (Brock et al. 1999; Bell et al. 2008). Water is received from small catchments by a combination of hydrological processes; some are mainly stream-fed, some spring-fed and some fed by overland flow. They are largely closed systems though water may spill into adjoining major river catchments. Based on extensive historical and recent field work only 58 lagoons have been identified within the New England Tablelands Bioregion of which only $28 \%$ are believed to be intact and in good condition (Bell et al. 2008).

Fens are found along watercourses on flat or concave valley floors from altitudes generally above $400 \mathrm{~m}$; the waters that feed them are comparatively mineral rich, alkaline or moderately acidic (Beadle 1981; Keith 2004; Hunter \& Bell 2009). Fens are dominated by soft-leaved tussock sedges (usually Carex species), grasses and semi-aquatic herbs and lack a sclerophyllous shrub component (Hunter \& Bell 2009). Prior to the current work Hunter \& Bell (2009) estimated that approximately 5000 ha of fens occurred in the New England Tablelands Bioregion with only $0.2 \%$ of these in conservation reserves. 
Bogs occur generally above $800 \mathrm{~m}$ elevation, on a broader range of physiographic positions with waters that are acidic and nutrient poor (Keith 2004;Whinam \& Hope 2005; Hunter \& Bell 2007). These bogs are structurally dominated by sclerophyllous shrubs (Hunter \& Bell 2007). Bogs are thought to be the more common wetland type within the New England Tablelands Bioregion potentially occupying 10000 ha of which $27 \%$ is within conservation reserves and potentially $80 \%$ of its original extent intact (Benson \& Ashby 2000; Hunter \& Bell 2007).
Australian montane wetlands are significant due to their rarity within the landscape; they are also under threat from continuing anthropogenic landuse practices such as grazing, draining, burning, dam construction, digging by pigs, nutrient addition and by climate change (Benson \& Ashby 2000; Whinam et al. 2001; Whinam \& Chilcott 2002; Hope \& Kershaw 2005; Hunter \& Bell 2007; Bell et al. 2008; Hunter \& Bell 2009, Hunter \& Bell 2013). All three wetland systems are included in listed Endangered Ecological Communities under the New South Wales

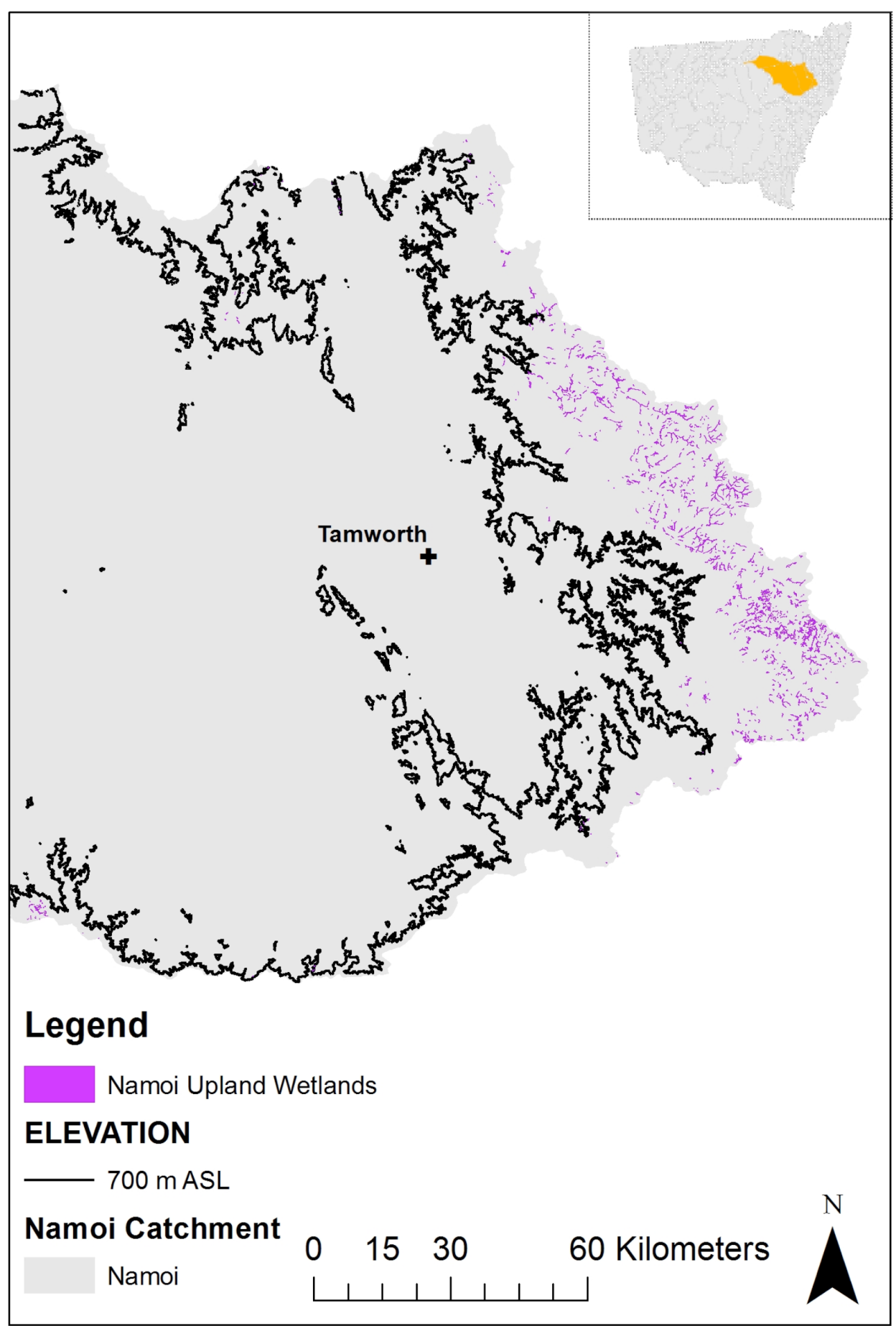

Fig. 1. The eastern half of the Namoi Catchment showing the location and mapping of Upland Wetlands above $700 \mathrm{~m}$ elevation along the eastern edge. 
Threatened Species Conservation Act (1995). Bogs and Fens dominated by Carex gaudichaudiana (Hunter \& Bell 2009) are incorporated within the Montane Peatlands and swamps of the New England Tableland, NSW North Coast, Sydney Basin, South East Corner, South Eastern Highlands and Australian Alps Bioregions Endangered Ecological Community determination. Fens not dominated by Carex gaudichaudiana are listed within Carex Sedgelands of the New England Tableland, Nandewar, Brigalow Belt South and NSW North Coast Bioregions community. Lagoons are listed under Upland Wetlands of the Drainage Divide of the New England Tableland Bioregion but are also listed on the Federal Environmental Protection and Biodiversity Act as Upland wetlands of the New England Tablelands and the Monaro Plateau.

Due to the paucity of information on the distribution of these wetland types and to assist planning and conservation strategies, a pilot project was undertaken to map the current distribution of the three wetland types in the Upland (above $700 \mathrm{~m}$ ) regions of the Namoi Catchment. The aims were to assess the area of each wetland type, how much is currently in conservation reserves, and the status of these remnants. The Namoi region was chosen as it was a designated priority area for Namoi Catchment Management Authority funding for landholders protecting wetlands in this region. Furthermore the region has an abundance of wetlands under various management titles allowing testing of the efficacy of mapping wetlands for wider application throughout the New England Tableland Bioregion. This paper reports on the results of that study.

\section{Methods}

In May 2012 available SPOT5 imagery (created 2006-2007) covering the Upland regions (above $700 \mathrm{~m}$ elevation) within the Namoi Catchment in northern New South Wales (Fig. 1) was extensively searched for wetlands. The Upland region lies to the south and west of the township of Uralla and covers areas to the east of Bingara, Bundarra, Tamworth, Nundle and parts of the Liverpool Range. At the time this was the only imagery to have complete coverage of the research area and the only images made available to the author. All wetlands discernible were digitised on-screen within ArcGIS 10.1 (projection: MGA Zone 56). In order to accurately capture the extent of the wetlands on-screen digitising and visualisation generally occurred at a scale of 1:10 000. As part of the mapping routine wetlands were scored for potential wetland type (Lagoon, Fen or Bog) and for degree of disturbance based on amount of surrounding vegetation cover and presence or absence of dams. The author's previous mapping experience, along with extensive on-ground wetland verification investigations during earlier survey and mapping exercises (in particular Hunter 2005; Hunter 2012) greatly assisted the identification of types but additional on-ground verification was also undertaken during the current mapping exercise (approximately four days fieldwork).
Six disturbance classes within two main groups were scored for each mapped wetland. Wetlands were scored for disturbance based on whether they occurred in a largely cleared landscape (less than $30 \%$ original surrounding vegetation cover), or whether they were found within primarily native vegetation ( $>30 \%$ of the original vegetation extant). Wetlands were then scored for presence of any dam within or on their boundary, if a dam was found within $150 \mathrm{~m}$ of the wetland boundary, or if the wetland had no dam in or within $150 \mathrm{~m}$ of any mapped boundary. Wetlands were scored as conserved if they occurred in conservation reserves under the management of the NSW Office of Environment and Heritage, or were from known Voluntary Conservation Areas.

\section{Results}

In total 1001 wetland polygons covering 4490 ha corresponded to the three wetland types (Fens, Bogs \& Lagoons) and were identified and mapped (Table 1). The smallest wetland was 0.12 ha in size with the largest being 113 ha. Average wetland size was 5 ha.

Fens accounted for the majority of wetlands mapped, accounting for $98.2 \%$ of the wetland area and 976 wetlands (Tables 1 \& 2). Only $3.8 \%$ (134.6 ha) of mapped fen area was within lands reserved for conservation. Of the 1001 wetlands, 24 (covering 81 ha) were mapped as bogs $(1.8 \%$ of all mapped wetlands). Of these $99 \%$ were within lands reserved for conservation (Tables $1 \& 2$ ). Bogs were restricted to the far southern boundary of the Namoi catchment with the majority in Coolah Tops National Park. Only a single lagoon (0.2 ha) was recorded from the Namoi Catchment (Tables $1 \& 2$ ). In total $5.5 \%$ of all wetland area is within conservation reserves (Table 1).

Only $13 \%$ of all wetlands were found within largely native vegetation (Table 2) and 10\% of the wetlands were within intact native vegetation and not influenced by a dam within their boundaries or within $150 \mathrm{~m}$ of their boundary (Table 2). $37 \%$ of all wetlands had a dam within their boundaries.

The results of the mapping project are considered highly accurate, due mainly to the extensive on-ground investigations and mapping of these wetlands previously conducted by the author, both in the Namoi region and across the upland areas of the New England Tableland Bioregion. However some wetlands may have been overlooked, some obscured by dense vegetation overstorey cover, or highly degraded wetlands dominated by introduced grasses and lacking characteristic wetland features. Intergrade wetlands where bog and fen elements occurred within the one wetland, though rare, have been found within the southern parts of the study area (pers. obs.). These intergrade wetlands may be due to natural influences or caused by human-induced changes in nutrient status and/or disturbance of substrates (Hunter \& Bell 2007; 2009). These are difficult to quantify in mapping and the area of bogs could have been underestimated as such areas were most likely to be included as fens during this exercise. However the results are unlikely to have been unduly affected. Such areas could not be directly mapped and would require on ground investigations. 
Table 1. Characteristics of the Upland Wetland types mapped in the Namoi catchment ( $>700 \mathrm{~m}$ elevation): area and proportion in conservation reserves

$\begin{array}{lcccc}\begin{array}{c}\text { Wetland } \\ \text { type }\end{array} & \begin{array}{c}\text { Total area } \\ \text { (ha) }\end{array} & \begin{array}{c}\text { Proportion of mapped } \\ \text { wetland area }\end{array} & \begin{array}{c}\text { Area in conservation } \\ \text { reserves (ha) }\end{array} & \begin{array}{c}\text { Proportion reserved } \\ \text { Bog }\end{array} \\ \text { Fen } & 41 & 2 \% & 80 & 99 \% \\ \text { Lagoon } & 4409 & 98 \% & 134 & 4 \% \\ \text { Total } & 0.2 & <.01 \% & 0 & 0 \% \\ & 4490 & 100 \% & 215 & 6 \%\end{array}$

Table 2. The number and type of upland wetlands recorded in the six disturbance categories in the Namoi catchment $(>700 \mathrm{~m}$ elevation) $(1=$ most disturbed, $6=$ least disturbed $)$.

Disturbance category

1. Cleared \& Dam

2. Cleared \& Dam within $150 \mathrm{~m}$

3. Cleared no Dam

4. Native Vegetation \& Dam

5. Native Vegetation \& Dam within $150 \mathrm{~m}$

6. Native Vegetation, no Dam

Total

\section{Discussion}

Previous mapping of Upland Wetlands (above $700 \mathrm{~m}$ elevation) within the Namoi Catchment by Ecological Australia (2009), was undertaken using the same imagery and methods as used in this current project, but described only 131 wetlands of which 35 were considered artificial (i.e. only 96 were natural wetlands). Sizes ranged from 0.25 ha to 110 ha with a mean of 11 ha (though the methodology states no wetlands under 1 ha were mapped). In the current mapping investigation the range of sizes was similar $(0.12$ - $113 \mathrm{ha})$ though the mean size was lower (5 ha). The current mapping however recorded 1001 natural wetlands, of which 626 wetlands were over 1 ha in size (if constrained to wetland $>0.25$ ha, 925 wetlands were mapped). The numbers of wetlands found in this survey therefore far exceed those presented by Ecological Australia (2009).

Only one wetland is listed under the EPBC Act, a lagoon 0.2 ha in size (called South Head by Bell et al. (2008)). The reservation of this isolated lagoon is important and measures should be taken to secure its continued persistence; only 58 lagoons in total are known from the New England Bioregion (Bell et al. 2008), the nearest lagoon to South Head being $43 \mathrm{~km}$ distant.

Hunter \& Bell (2009) postulated that as little as 5000 ha of fens occurred in the New England Bioregion, but although the upland areas of the Namoi Catchment are a prime area for the occurrence of fens, it is obvious from the results here (4 400 ha are found in this region alone) that this number was an underestimate. Based on the current mapping it is likely that the New England Bioregion probably contains an order of magnitude more fens than previously thought; it is suggested here that there is likely to be $30000-50000$ ha of fens across the New England Bioregion.

Within the Namoi Catchment the proportion of fens protected in conservation reserves is about $4 \%$; higher than Hunter \& Bell (2009)'s assessment that $0.2 \%$ of fens in the New England Bioregion were within conservation reserves. This discrepancy may be a local phenomenon, due to recent acquisitions (since 2009) of Crown lands for conservation reserves that include large fens and significantly increased the protection of fens within the Namoi. However $4 \%$ is still a very low level of reservation, and as only $10 \%$ of all fens within the upland Namoi Catchment are relatively undisturbed i.e. within largely native vegetation and unaffected by dams, further reservation of fens through conservation mechanisms such as Voluntary Conservation Agreements is still a priority.

For the New England Bioregion Hunter and Bell (2007) considered bogs to be better reserved than fens, and within the Namoi study region nearly all bogs were in reserves and unaffected by dams or agricultural clearing. Bogs were largely restricted to high altitude locations along the southern boundary of the Namoi Catchment such as in the Coolah Tops (Binns 1997) and the Ben Halls Gap areas (Whinam \& Chilcott 2002).

This mapping program has highlighted that fens occupy a larger area than previously thought, however that they are still a highly unrepresented community type within the reserve system. Only $8 \%$ of fen wetlands within the Namoi Catchment are in near natural condition (Table 2). Bogs on the other hand are rarer within the Namoi Catchment but are well reserved, in good condition and therefore of a lesser reservation priority within this region. As only a single lagoon occurs within the Namoi Catchment it is a priority that this is protected in the near future. The success of this pilot study indicates that this mapping could be extended across the rest of the New England region and with the use of better imagery such as ADS40 better understanding and more efficient prioritisation of conservation activities could occur. 


\section{Acknowledgements}

Thanks to Dorothy Bell for assistance during our previous investigations into all the wetland types discussed in this article. Bob Haworth is also thanked for his assistance with the Lagoon research. Southern New England Landcare is thanked for the impetus and encouragement to carry out the preliminary mapping exercise on the Namoi upland wetlands.

\section{References}

Beadle, N.C.W. (1981) The vegetation of Australia. Cambridge University Press, Cambridge.

Bell, D., Hunter, J.T. \& Haworth, R.J. (2008) Montane lagoons of the New England Tablelands Bioregion: vegetation, landuse and dynamics. Cunninghamia 10: 475-492.

Benson, J.B. \& Ashby, E.M. (2000) Vegetation of the Guyra 1:100 000 map sheet New England Bioregion, New South Wales. Cunninghamia 6: 747-872.

Binns, D.L. (1997) Floristics and vegetation patterns of Coolah Tops, New South Wales. Cunninghamia 5: 233-274.

Brock, M.A., Smith, R.G.B, \& Jarman, P.J. (1999) Drain it, dam it: Alteration of water regime in shallow wetlands on the New England Tableland of New South Wales. Wetlands Ecology and Management 3: 37-46.

Eco-logical Australia (2009) Upland Wetlands of the Namoi Catchment: Assessment of Current Datasets Limitations. Unpublished report prepared for the Namoi Catchment Management Authority.

Hope, G. \& Kershaw, P. (2005) Montane swamps of eastern Australian. Stapfia 85: 412-413.

Hunter, J.T. (2005) Vegetation and floristics of Aberbaldie Nature Reserve. Unpublished report to Walcha District, NSW National Parks \& Wildlife Service.

Hunter, J.T. (2012) Vegetation and floristics of Warrabah National Park, supplementary appendix: Survey of Stone Hut Addition. Unpublished report to the NSW Office of Environment and Heritage.

Hunter, J.T. \& Bell, D. (2007) The vegetation of montane bogs in eastern flowing catchments of the New England Batholith, New South Wales. Cunninghamia 10: 77-82.

Hunter, J.T. \& Bell, D. (2009) The Carex Fen vegetation of northern New South Wales. Cunninghamia 11: 49-65.

Hunter, J.T. \& Bell, D. (2013) Season and timing of moisture availability predict composition of montane shrub dominated wetlands at distributional limits in eastern Australia. Australian Journal of Botany 61, 243-253.

Keith, D.A. (2004) Ocean shores to desert dunes: the native vegetation of New South Wales and the ACT. NSW Department of Environment and Conservation: Hurstville.

Whinam, J.\& Chilcott, N. (2002) Floristic description and environmental relationships of Sphagnum communities in NSW and the ACT and their conservation management. Cunninghamia 7: 463-500.

Whinam, J. \& Hope, G. (2005) The peatlands of the Australasian region. Stapfia 85: 397-400.

Manuscript accepted 24 September 2013 